\title{
‡USGS
}

science for a changing world

\section{Geochemical Database for the Boulder Batholith and lts Satellitic Plutons, Southwest Montana}

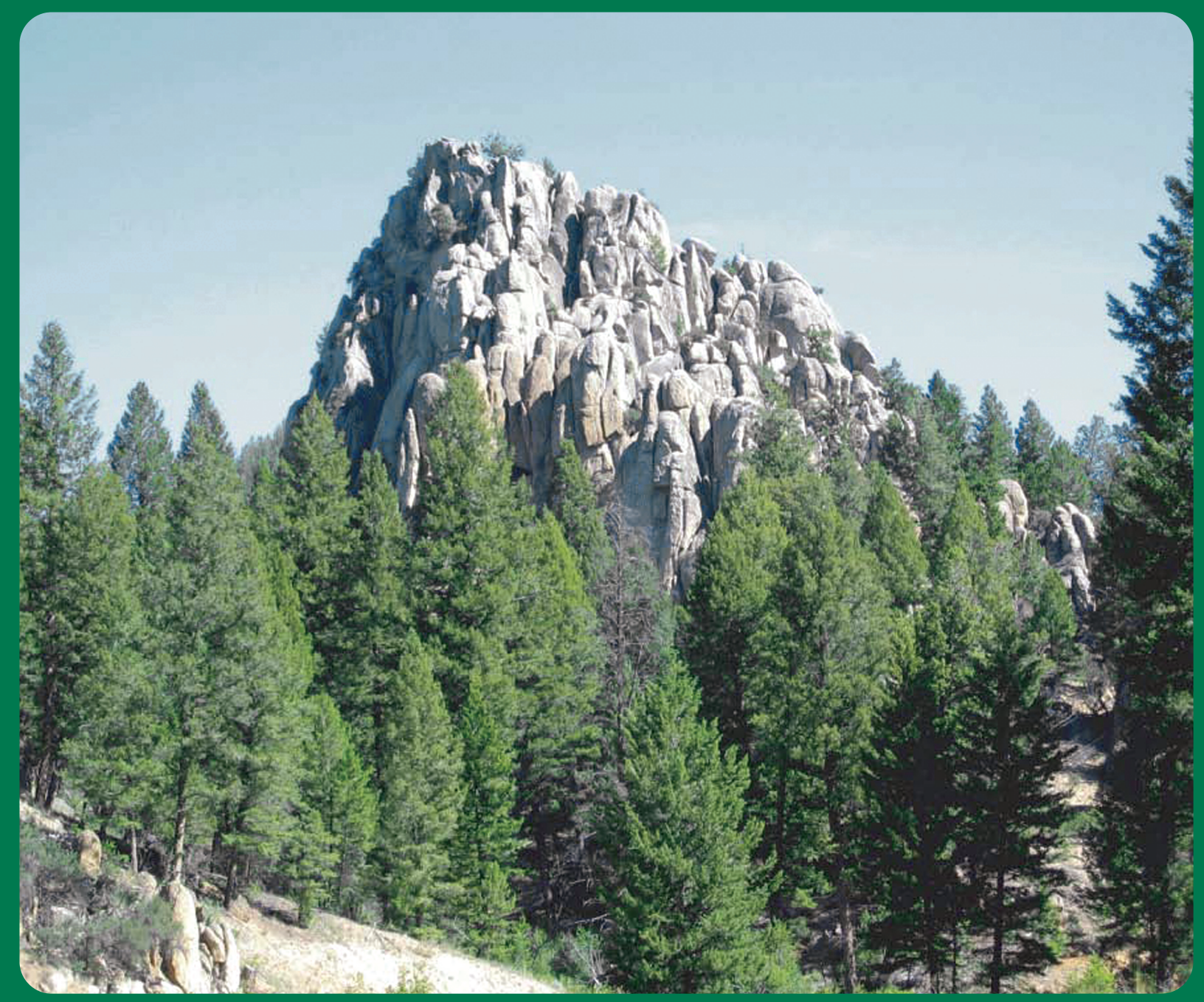

\section{Data Series 454}


Cover photograph:

Prominent outcrops of the Moose Creek pluton in the Humbug Spires area, southern Boulder batholith, Montana 


\section{Geochemical Database for the Boulder Batholith and Its Satellitic Plutons, Southwest Montana}

By Edward A. du Bray, Karen Lund, Robert I. Tilling,

Paul D. Denning, and Ed DeWitt

Data Series 454 


\title{
U.S. Department of the Interior \\ KEN SALAZAR, Secretary
}

\section{U.S. Geological Survey \\ Suzette M. Kimball, Acting Director}

\author{
U.S. Geological Survey, Reston, Virginia: 2009 \\ Version 1.0
}

\begin{abstract}
For more information on the USGS — the Federal source for science about the Earth, its natural and living resources, natural hazards, and the environment, visit http://www.usgs.gov or call 1-888-ASK-USGS

For an overview of USGS information products, including maps, imagery, and publications, visit http://www.usgs.gov/pubprod

To order this and other USGS information products, visit http://store.usgs.gov
\end{abstract}

Any use of trade, product, or firm names is for descriptive purposes only and does not imply endorsement by the U.S. Government.

Although this report is in the public domain, permission must be secured from the individual copyright owners to reproduce any copyrighted materials contained within this report.

Suggested citation:

du Bray, E.A., Lund, Karen, Tilling, R.I., Denning, P.D., and DeWitt, Ed, 2009, Geochemical database for the Boulder batholith and its satellitic plutons, southwest Montana: U.S. Geological Survey Digital Data Series 454, 1 CDROM. [Available at URL http://pubs.usgs.gov/ds/454] 


\section{Contents}

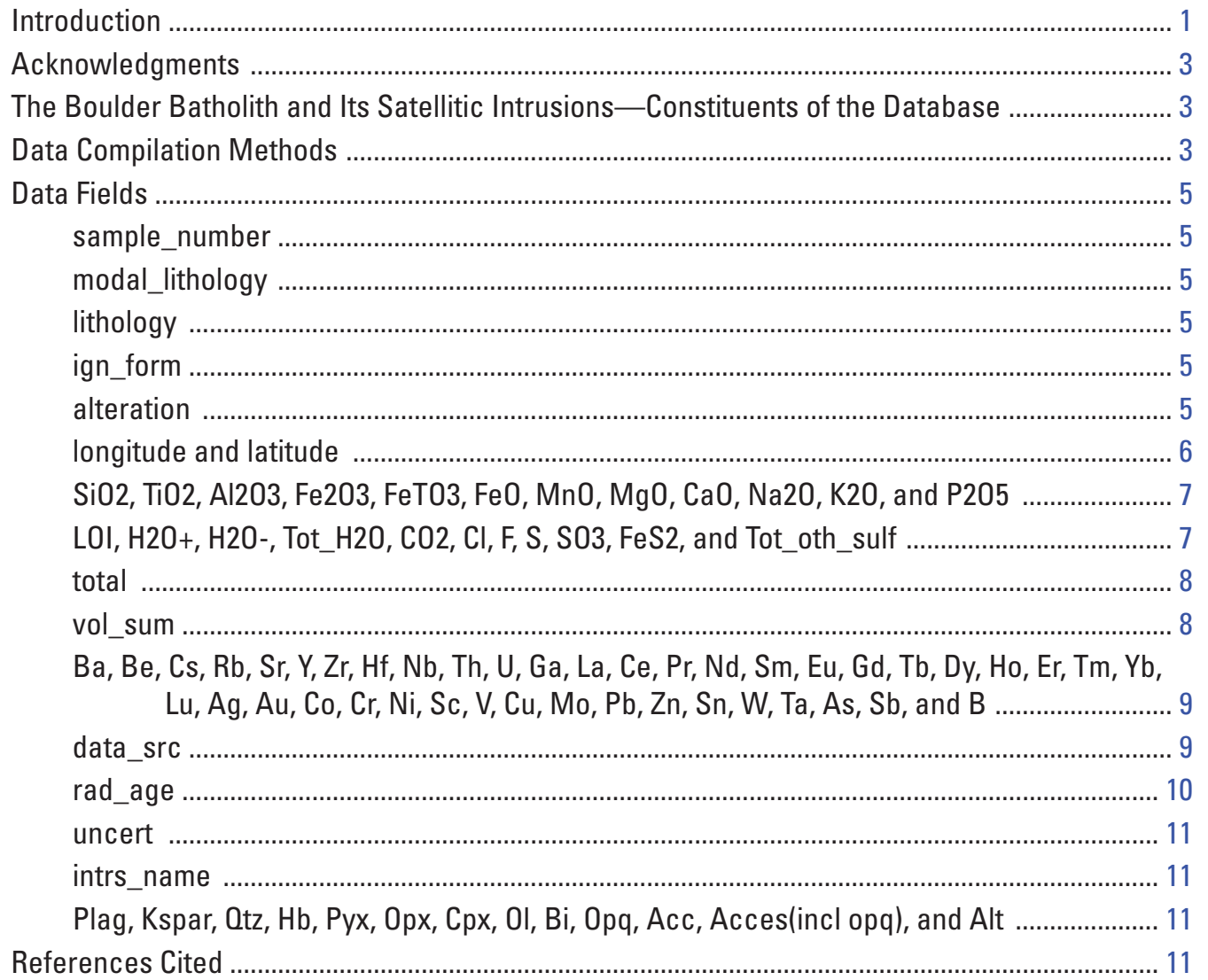

\section{Figures}

1. Index map showing the Boulder batholith and its satellitic plutons, southwest Montana ........ 2

2. Quartz-alkali feldspar-plagioclase ternary diagram showing modal compositions of Boulder

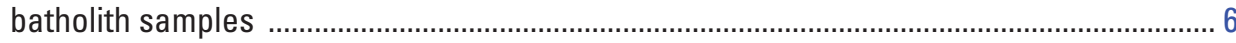

3. Total alkali-silica variation diagram showing compositions of the Boulder batholith and its satellitic plutons, southwest Montana ............................................................................ 7

4. $\mathrm{FeO}^{*} /(\mathrm{FeO}+\mathrm{MgO})$ versus $\mathrm{SiO}_{2}$ variation diagram showing compositions of the Boulder batholith and its satellitic plutons, southwest Montana ............................................................ 8

5. $\mathrm{Na}_{2} \mathrm{O}+\mathrm{K}_{2} \mathrm{O}-\mathrm{CaO}$ versus $\mathrm{SiO}_{2}$ variation diagram showing composition of the Boulder batholith and its satellitic plutons, southwest Montana ............................................................... 9

6. Trace-element, tectonic-setting-discrimination variation diagram showing composition of the Boulder batholith and its satellitic plutons, southwest Montana ...................................... 10 


\section{Plate}

1. Preliminary map of plutonic units of the Boulder batholith, southwestern Montana [see separate tıle] 


\title{
Geochemical Database for the Boulder Batholith and Its Satellitic Plutons, Southwest Montana
}

\author{
By Edward A. du Bray, Karen Lund, Robert I. Tilling, Paul D. Denning, and Ed DeWitt
}

\section{Introduction}

Data presented in this report pertain to Cretaceous igneous intrusions of the Boulder batholith and its satellitic plutons in southwest Montana. As summarized by Lund and others (2002), the Boulder batholith consists of the Butte Granite ${ }^{1}$ and an array of satellitic plutons emplaced into Mesoproterozoic to Mesozoic sedimentary rocks and possibly cogenetic rocks of the Late Cretaceous Elkhorn Mountains Volcanics (Hamilton and Myers, 1967; Robinson and others, 1968; Klepper and others, 1971a, b; Tilling, 1974; Lambe, 1981; and Rutland and others, 1989). Data presented here were compiled during 2007 and 2008 as part of the updated National Mineral Resources-Planning Phase project conducted by the U.S. Geological Survey (USGS) in order to help place worldclass mineral deposits of the Butte district into an appropriate framework relative to associated intrusive rocks. Although these deposits and their host rocks have been the subject of many investigations (Brown, 1894; Emmons and Tower, 1897; Weed, 1912; Knopf, 1913, 1950; Sales, 1913; Sales and Meyer, 1948, 1949; Meyer, 1965; Smedes, 1966; Meyer and others, 1968; Lange and Cheney, 1971; Brimhall, 1973, 1977, 1979, 1980; Miller, 1973; Proffett, 1973; Roberts, 1975; Rusk and others, 2008), the petrologic characteristics of associated intrusive rocks have not been systematically compiled, synthesized, or interpreted, with the exception of some analytical studies of rocks and (or) minerals of the Boulder batholith (Tilling, 1964, 1968, 1973, 1974, 1977; Doe and Tilling, 1967; Doe and others, 1968; Greenland and others, 1968, 1971, 1974; Tilling and Gottfried, 1969; Gottfried and others, 1972). The geographic area addressed in this compilation is approximately bounded by lats $45.6^{\circ}$ and $46.7^{\circ} \mathrm{N}$. and longs $112.75^{\circ}$ and $111.5^{\circ}$ W. (fig. 1). The area is dominated by the voluminous Butte Granite, but as many as a dozen other significant plutons surround this very large pluton. In addition, small stocks and plugs are numerous north and especially east of

\footnotetext{
${ }^{1}$ See "lithology" section for rationale considered in changing the name of the Butte intrusion from quartz monzonite to granite.
}

the Butte Granite, where they intruded the Elkhorn Mountains Volcanics. Abundant late Mesozoic intrusions in the study area are probably byproducts of subduction-related processes, including back-arc magmatism that prevailed along the west edge of the North American plate during this interval.

Lund and others (2002) and Rusk and others (2008), for example, have highlighted the association between magmatism and ore deposits in the area of the Boulder batholith. More than a century of geologic investigations in the study area demonstrate that many ore deposits, representing diverse deposit types, are spatially, and probably temporally and genetically, associated with igneous intrusions. Because of the significance of mineral deposits associated with the Boulder batholith, many investigations of these deposits have been completed, including those by Master's and Doctoral thesis students (particularly University of California, Berkeley, and both Oregon and Oregon State University students and associated faculty), economic geologists working on behalf of exploration and mining companies, and USGS earth scientists. These studies have produced many igneous rock geochemical analyses, but despite the number and importance of igneous intrusions in the study area, no complete synthesis of these data has been completed.

Starting in the 1950s, USGS personnel began a significant geologic mapping and geochemical analysis campaign in the Boulder batholith region (see references, especially sources of mapping, compiled by Smedes and others, 1988). The principal impetus for these investigations was U.S. Atomic Energy Commission funding dedicated to an assessment of uranium resource potential associated with these rocks. This first episode of study concluded about 1956 and was summarized in an unpublished report prepared by Randolph W. Chapman (Trinity College, Hartford, Conn.). Subsequently, geologic mapping continued, and in the early 1960s R.I. Tilling of the USGS initiated a second round of petrologic research, which included collecting and analyzing additional rock samples and mineral concentrates. This work culminated in two seminal papers about the Boulder batholith and associated rocks (Tilling, 1973, 1974). Unfortunately, much of the data synthesized and interpreted in these papers 


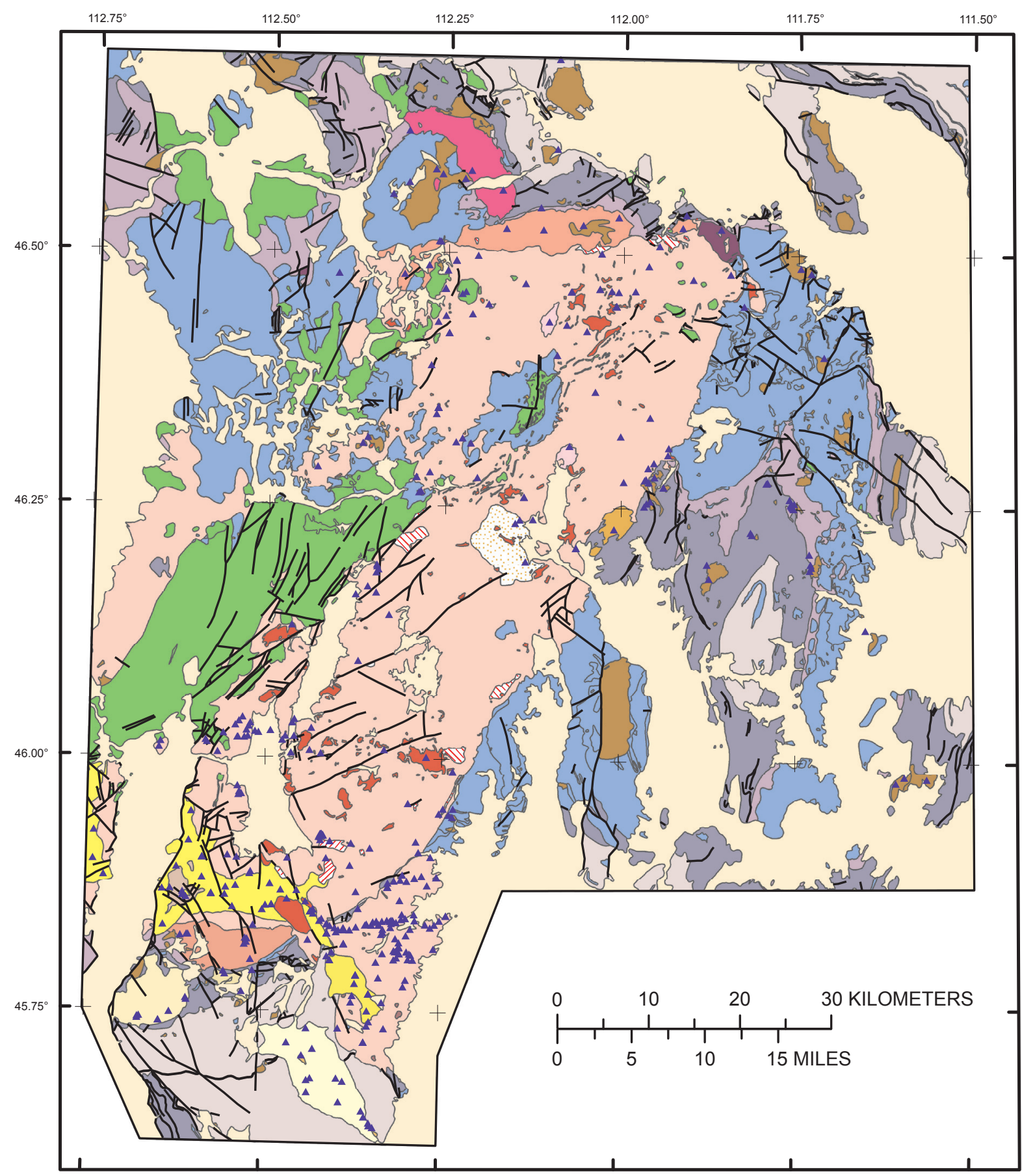

\begin{tabular}{|c|c|c|c|}
\hline & EXPLANATION & & \\
\hline Quaternary surficial deposits & Mafic intrusive rocks & & Granodiorite of Rader Creek \\
\hline Tertiary volcanic rocks & Climax Gulch pluton & & Mafic intrusions \\
\hline Granophyre & Younger granitic rocks & & Satellitic intrusions of the Boulder batholith \\
\hline Granite porphyry & Hell Canyon pluton & & Elkhorn Mountains Volcanics \\
\hline Monzogranite at Homestake & Aplite & & Mesozoic and upper Paleozoic sedimentary rocks \\
\hline Monzogranite of Pulpit Rock & Donald pluton & & Paleozoic sedimentary rocks \\
\hline Felsic monzogranite & Moose Creek pluton & & Precambrian rocks \\
\hline Butte Granite & Moosetown pluton & & Contact \\
\hline Unionville Granodiorite & Unnamed plutons & - & Fault \\
\hline Granodiorite of Burton Park & Porphyritic granodiorite of Knopf (1963) & $\Delta$ & Sample location \\
\hline
\end{tabular}

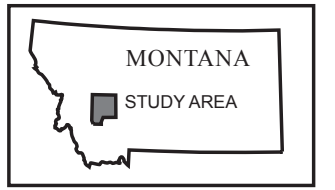

Figure 1. Index map showing the Boulder batholith and its satellitic plutons, southwest Montana (modified from Smedes and others, 1988). 
remained unpublished (see fig. 4 caption in Tilling, 1973). Soon thereafter, L.K. McClain (Bauer), G.W. Matthews, and colleagues extensively sampled and analyzed rocks of the Boulder batholith as part of the National Uranium Resource Evaluation (NURE) conducted by the U.S. Department of Energy. The resulting, never-published data (analyses of nearly 100 samples) were preserved in a single paper copy of analytical results in the files of R.I. Tilling (L.K. McClain and G.W. Matthews, unpub. data, 1979). Lambe (1981) completed a Ph. D. thesis concerning the petrology of the Boulder batholith rocks but once again pertinent data remained unpublished. Subsequently, interest in Boulder batholith intrusive rocks waned, and significant additional research on these rocks did not recommence until about 10 years ago, during the USGS Headwaters Project (Lund and others, 2002; Lund, 2007) and with renewed academic interest, coordinated principally by J.H. Dilles (Oregon State University, Corvallis, Oreg.), M.H. Reed (University of Oregon, Eugene, Oreg.), and their students. Now, with the USGS about to initiate an updated National Mineral Resource Assessment (Johnson and others, 2008), it is important that the genetic understanding of giant deposits, such as those associated with the Boulder batholith, be refined to reduce uncertainties of mineral resource assessments. To fully understand the Boulder batholith and its associated deposits, it is essential to develop, synthesize, and interpret the magmatic framework within which these evolved. The text and data that follow contain a synthesis of available composition data for igneous rocks of the Boulder batholith area. The ultimate goal of this effort will be an evaluation of the time-space-compositional evolution of Mesozoic magmatism associated with the Boulder batholith and identification of genetic associations between magmatic and mineralizing processes in this region.

\section{Acknowledgments}

We thank several individuals who helped make this effort possible. The staff of the USGS Denver library, who used the interlibrary loan process to obtain some of the geologic reports on which parts of this compilation are based, were critical to its success. R.N. Lambe helped establish location information for many samples included in his research. S.M. Smith and Matthew Granitto extracted geochemical data for samples of the Boulder batholith from the USGS National Geochemical Database (NGDB). Matthew Granitto was also instrumental in searching for Boulder batholith data in paper archives to find original laboratory reports that contained data for Boulder batholith samples that had never been entered into the NGDB. Finally, we gratefully acknowledge technical reviews by Matthew Granitto and R.M. O'Leary that helped to improve this report.

\section{The Boulder Batholith and Its Satellitic Intrusions- Constituents of the Database}

The data compilation described here pertains to the very large Butte Granite pluton, approximately a dozen contiguous smaller plutons generally considered to be part of the Boulder batholith, and numerous isolated small stocks and plugs that are especially abundant north and east of the Butte Granite (fig. 1). The Elkhorn Mountains Volcanics also include many hypabyssal intrusions; however, compositional data for these rocks are not included in the compilation. These fine-grained to aphanitic basaltic and andesitic rocks form moderately large, concordant intrusions that are demonstrably associated with the Elkhorn Mountains Volcanics. In contrast, satellitic intrusions considered to be parts of the Boulder batholith form small, discordant, phaneritic intrusions. Applying the emerging K-Ar dating technique, Tilling and others (1968) estimated the time span of emplacement of the Boulder batholith to about 6 million years ( $\approx 78-72 \mathrm{Ma})$. Modern $\mathrm{U}-\mathrm{Pb}$ zircon geochronologic investigations (Lund and others, 2002) have confirmed that all intrusions of the Boulder batholith are Cretaceous. Aside from the granodiorite of Rader Creek (80.7 Ma) and the Unionville Granodiorite (78.2 Ma), ages of Boulder batholith plutons are restricted to the 77.6-73.7 Ma interval; the age of the Butte Granite ranges from 76.5 to 74.5 Ma (Lund and others, 2002). However, early K-Ar age data (McDowell, 1966) suggest that one of the Boulder batholith intrusions, the Climax Gulch pluton, might be as young as $\approx 68 \mathrm{Ma}$. The Boulder batholith also includes quartz porphyry dikes and plugs that are distinctly younger than other batholith rocks. Most ages determined for these rocks are in the 70.0-67.6 Ma age interval, although zircon from a rhyolite dike and from the informal Modoc breccia quartz porphyry intrusion gives ages of 62.7 Ma and 77.3 Ma (J.N. Aleinikoff, USGS, unpub. data, 2009), respectively. Ages have not been determined for any of the small satellitic masses that discordantly intruded the Elkhorn Mountains Volcanics.

\section{Data Compilation Methods}

The map compilation of Smedes and others (1988) was used as the geologic framework for our geochemical compilation. That map identifies the intrusions for which geochemical data were compiled. Intrusion names were gleaned from publications on which that compilation is based. The original, stable-base geologic compilation of Smedes and others (1988) was scanned and attributed to produce an ArcGIS rendition of the map; associated data are included with the data release described here. The locations of samples for which geochemical data were compiled as part of this endeavor were combined with the ArcGIS data to create a PDF file (file, DS454_Plate.pdf) to which all intrusion names were added (pl. 1). Metadata for the 
ArcGIS files are embedded in the geospatial database and are also contained in a freestanding file (file, Metadata.txt).

Several significant efforts to acquire and compile compositional data for Boulder batholith intrusions preceded and served as a starting point for the effort documented here. Compilations by R.W. Chapman (Trinity College, Hartford, Conn., unpub. data, 1956), Tilling (1973), L.K. McClain and G.W. Matthews (NURE, unpub. data, 1979), and Lambe (1981) constitute the majority of the compiled data; all other data were compiled from published sources. Much of the data compiled, plotted, and interpreted by Tilling (1973) have never been published and were recently recovered from original paper copies of lab analysis reports. The McClain and Matthews data are essentially undocumented; original lab reports are unavailable.

Original data source materials (subsequently referred to as sources), including published reports and theses, were used to add information to the database. Compiling analytical methods and associated estimates of precision and accuracy associated with the reported data was beyond the scope of this effort. Analytical protocols, precision, and accuracy were highly variable among sources. Fortunately, most sources document these parameters so that associated questions can be resolved by referring to the appropriate data source. Reference lists contained in the data sources were examined and used to identify additional potential data sources. In this way, data for 435 samples from 22 sources were identified and incorporated in the database. We believe that this process has probably resulted in identification and incorporation of most of the compositional data that have been produced for samples of Boulder batholith intrusions. For a sample to be included in the database, at least a sample number and major oxide analysis were required. Additional trace element and (or) isotopic data may be available for some samples (Doe and Tilling, 1967; Doe and others, 1968; Greenland and others, 1968, $1971,1974)$, but because the number of these samples is very small, these data were not included in the database. Small amounts of additional data can be gleaned by consulting the appropriate data sources. Data were compiled using Microsoft Excel and can be accessed using software compatible with .xls files. The database release file is titled ButteChem.xls. The database release also includes a tab-delimited, text file version of the database (file, ButteChem.txt).

No effort was made to exclude hydrothermally altered samples from the compilation. Rather, all intrusive rock compositional data were compiled, and samples identified by the sources as altered were coded accordingly. Additional altered samples were identified using standard geochemical criteria. Specifically, for the purposes of this compilation, hydrothermally altered samples are those with any of the following characteristics: $\mathrm{SiO}_{2}$ abundances greater than 78 percent, $\mathrm{Al}_{2} \mathrm{O}_{3}$ abundances less than 10 percent or greater than 20 percent, total volatile concentrations greater than 3 percent, $\mathrm{CO}_{2}$ concentrations greater than 0.35 percent, $\mathrm{S}$ concentrations greater than 0.2 percent, or Total_oth_sulf concentrations greater than 0.2 percent; samples with any of these characteristics probably do not preserve primary igneous rock compositions. In addition, samples with initial analytic totals greater than 103 percent or initial analytic totals less than 95 percent were identified; samples with these characteristics probably indicate unusable, inaccurate analyses.

Starting with data contained in the principal compilation (accessed via the "Butte DB" tab; file, ButteChem.xls), data winnowing and processing resulted in two derivative databases, accessed via the "Nml db no alt cens Fe2" and "Alt" tabs (file, ButteChem.xls), that were both processed (to enhance their ready usability) from the principal compilation (as described in the following). First, all censored values were replaced by blank cells. Next, because different sources report iron concentrations determined by different analytical protocols, the mode of iron abundance data presentation required standardization. For most samples, abundances of both ferric and ferrous iron (compiled in the $\mathrm{Fe}_{2} \mathrm{O}_{3}$ and $\mathrm{FeO}$ data columns, respectively) are reported in the sources. Some compiled analyses report only total iron abundances (compiled in the $\mathrm{FeTO}_{3}$ column) as ferric iron, and analyses of a few samples contain data for ferrous iron only. Reported ferrous and ferric iron abundances in many of these rocks are unlikely to represent magmatic values because of oxidation during late- to post-magmatic processes. Interaction with post-magmatic fluids caused compositions of many Boulder batholith intrusive rocks to change in other ways as well. In particular, many of these rocks were hydrothermally altered (as indicated by secondary clay minerals, sericite, and (or) chlorite). Late magmatic processes and alteration caused volatile concentrations of the affected samples to increase, and correspondingly caused relative abundances of all other constituents to decrease. Therefore, to facilitate meaningful comparison of oxide abundances between variably altered samples, all iron abundances were converted to ferrous iron (compiled in the $\mathrm{FeO}^{*}$ column) and each major oxide analysis was recalculated to 100 percent on a volatile-free basis. The derivative database for essentially unaltered intrusive samples accessed via the "Nml db no alt cens Fe2" tab can be used to evaluate timespace-compositional relations between magmatism and ore genesis. The associated spreadsheet includes data for unaltered samples only and no censored data; portrays total iron concentrations as ferrous iron; and presents major oxide analyses recalculated to 100 percent on a volatile-free basis. The derivative database containing information for altered rocks can be accessed via the tab labeled "Alt" and can be used to evaluate the effects of hydrothermal alteration on primary rock compositions. The associated spreadsheet includes data for all altered samples and no censored data, and also presents total iron concentrations as ferrous iron and major oxide analyses recalculated to 100 percent on a volatile-free basis. Row entries in the data accessed via the "Alt" tab are sorted into subsets of samples that share the same alteration characteristic (in red, at the top of each subset of data rows).

Data presented in source materials were included in the database, without modification, and all input subsequently verified. Background documentation for some analytical data 
presented in this report is incomplete and (or) may be misleading or incorrect, any of which could cause inclusion of inappropriate information in the database. Every effort has been made to preclude inclusion of misleading data; the amount of this type of data inadvertently included in the database is probably small and should not significantly affect data interpretation.

\section{Data Fields}

Data fields presented and described herein represent those considered most critical to addressing questions concerning tectonic, petrologic, and metallogenic relations. Data for each of these fields constitute a column, or set of related columns, in the database. Data in these columns can be sorted, queried, and interpreted to address questions concerning the history, development, and implications of magmatic activity. Sample records are aggregated in blocks of data that share a primary geochemical data source.

Blank cells in the main "Butte DB" database indicate that no data are available for the corresponding column. Some sources report values of zero for some database fields. These values indicate that an abundance determination was attempted but that the constituent was not detected in the sample. Similarly, some sources present qualified data. In particular, records for some samples include less than $(<)$ symbols. These data indicate that the constituent was detected but that its concentration was unquantifiable beyond the fact that its concentration is less than the indicated value. Analytical precision varies within individual columns in accordance with specific analytical protocols and the way data are reported in individual sources.

\section{sample_number}

Identifiers for analyzed samples were compiled from sources and presented, without modification.

\section{modal_lithology}

Lithologic names of analyzed samples were derived from information contained in sources. In accordance with procedures defined by the International Union of Geological Sciences (IUGS), lithologic/composition names for intrusive rocks are best defined using the relative modal proportions of quartz, alkali feldspar, and plagioclase relative to the classification scheme of Streckeisen (1976). However, many publications that serve as sources for our compilation predate the classification recommendations of Streckeisen (1976); most of these used the classification of Johannsen (1931) to define sample lithology. Using modal data available for each sample, lithologic sample designations in the "modal_lithology" column have been verified, corrected, and converted from the nomenclature of Johannsen (1931) to that of Streckeisen
(1976). As discussed by Lund and others (2002), the Butte pluton is actually composed (Streckeisen, 1976) of granite (more specifically, monzogranite). As such we refer to this intrusion as the Butte Granite, using the original nomenclature of Emmons (1888). For the same reason, we refer to the informal Homestake, Pulpit Rock, and felsic quartz monzonites of Smedes and others (1988) as the Homestake, Pulpit Rock, and felsic monzogranites. Modal data for samples of the Boulder batholith and its surrounding satellitic intrusions are summarized on a ternary quartz-alkali feldspar-plagioclase diagram (fig. 2). In recognition of the distinctive cuneiform textures characteristic of many of the aplite-alaskite-pegmatite bodies, we refer to intrusions whose lithologies are coded as aplite, alaskite, or alaskite-aplite as "granophyre."

\section{lithology}

Modal data are not available for many samples included in the database. Lacking this data, original lithologic names (entries in the "lithology" column) designated in the sources were retained; these are approximate lithologic designations not supported by available modal data.

\section{ign_form}

The form of the igneous intrusion represented by each sample is given where known. Samples coded as representing dikes, sills, or dike/sill represent thin tabular bodies that are discordant and concordant with enclosing rocks, respectively. Larger intrusive bodies, generally discordant to enclosing rocks, are coded as plutons and stocks. "Pluton" entries in the "ign_form" column identify intrusions that cooled slowly, at least several kilometers below the surface, and are phaneritic, whereas "Stock" entries designate smaller intrusions, many of which cooled relatively quickly at shallow levels in a subvolcanic environment, and may have a quenched groundmass. Smedes and others (1988) suggested that the aplite-alaskitepegmatite bodies (granophyre) form gently dipping sheets; "ign_form" entries for samples of these units are coded as "Dike" or "Sill" depending on field relations or left blank if not known. They also suggest that the Moose Creek intrusion is a moderately inclined, irregular-shaped laccolith; "ign_form" entries for samples of this unit are coded "Laccolith."

\section{alteration}

Some sources explicitly indicate that some analyzed samples are altered. Other sources provide sufficient descriptive information about samples that alteration can be inferred. Some sources simply indicate that samples are altered; these samples are simply coded as "Yes" in the "alteration" column. Other alteration terms used to code altered samples include argillic, propylitic, and sericitic. Each of these terms is 
applied in accordance with their standard usage as defined by Guilbert and Park (1986).

\section{longitude and latitude}

An effort was made to obtain location data for all samples with composition data. Most sources contain some form of location information. Missing sample location data were requested from authors, most of whom were able to provide missing information. Accordingly, location data are available for all but a few samples. Latitude and longitude data are reported as decimal degrees (relative to the 1927 North American Datum). In the study area, longitude is reported as a negative value (western hemisphere) and latitude as a positive value (northern hemisphere).

Location data are of variable quality as a consequence of the manner in which they were initially acquired and subsequently reported. The number of significant figures presented as part of location data in the "longitude" and "latitude" columns defines relative levels of sample location precision, as follows:

- four significant figures indicate that the given location is accurate within tens of meters,

- three significant figures indicate that the given location is accurate within hundreds of meters, and

- two significant figures indicate that the given location is accurate within thousands of meters.

Some sources report sample location in terms of Township, Range, and section values, usually to the closest quarter section. Township-Range-section data were digitized to obtain decimal degree locations; within the appropriate quarter section quadrilaterals, digitized points were usually selected to coincide with a road, trail, stream bottom, quarry, or natural cliff, any of which might represent a likely sampling location. Some sources do not include numerical sample location data

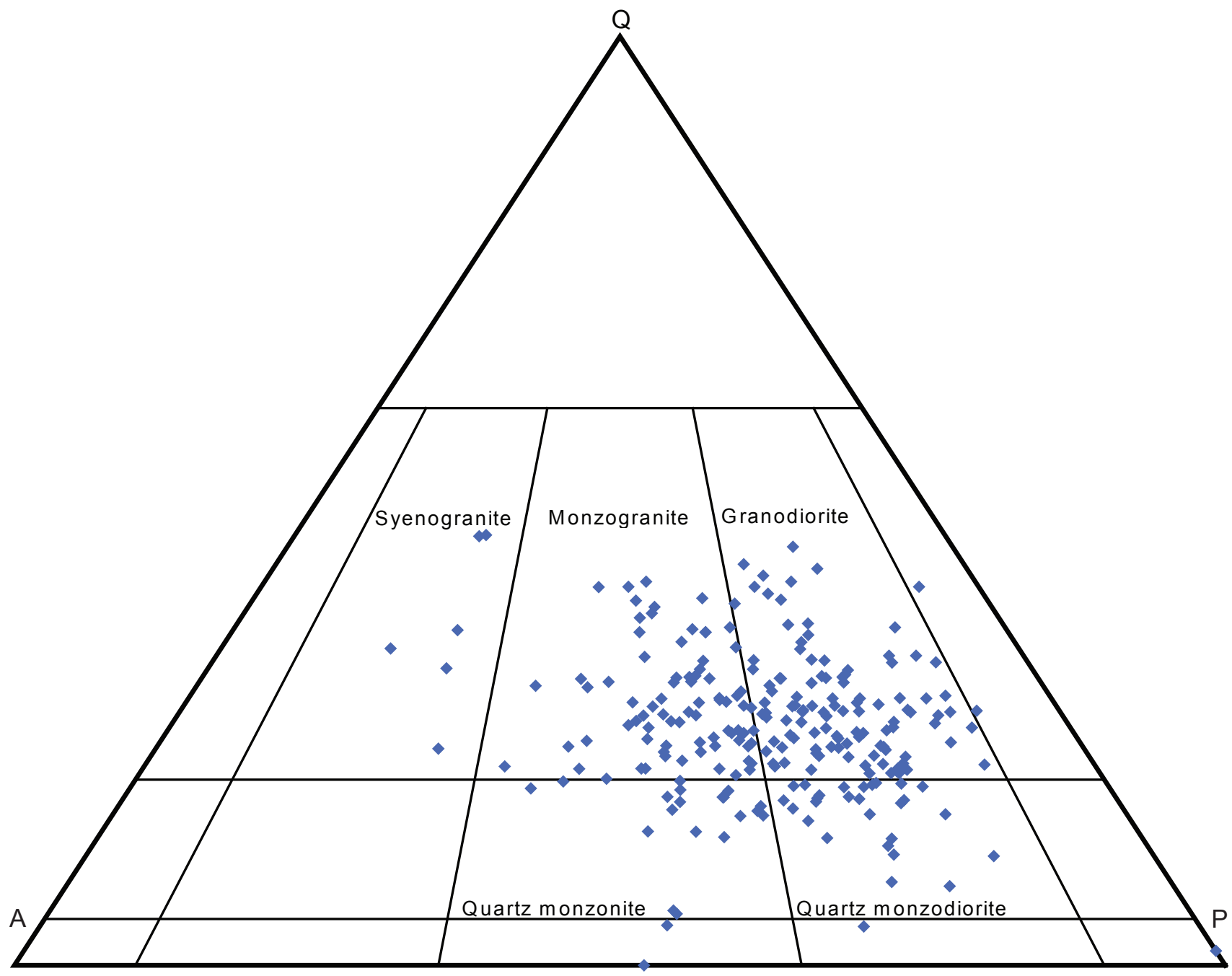

Figure 2. Quartz (Q)-alkali feldspar (A)-plagioclase (P) ternary diagram showing modal compositions of Boulder batholith samples. Classification grid and rock names are those of Streckeisen (1976). 
but do contain sample maps. Location data for these samples were obtained by digitizing sample sites. A very few sources merely describe sample locations; these were used to estimate a sample location, which was then digitized.

\section{$\mathrm{SiO2,} \mathrm{Ti02,} \mathrm{Al203,} \mathrm{Fe203,} \mathrm{FeT03,} \mathrm{Fe0,} \mathrm{Mn0,}$ $\mathrm{MgO}, \mathrm{CaO}, \mathrm{Na2O}, \mathrm{K2O}$, and P2O5}

Sources report whole rock, major oxide data in a variety of formats. The database includes columns for the abundances (in weight percent) of $\mathrm{SiO}_{2}, \mathrm{TiO}_{2}, \mathrm{Al}_{2} \mathrm{O}_{3}, \mathrm{Fe}_{2} \mathrm{O}_{3}, \mathrm{FeTO}_{3}, \mathrm{FeO}$, $\mathrm{MnO}, \mathrm{MgO}, \mathrm{CaO}, \mathrm{Na}_{2} \mathrm{O}, \mathrm{K}_{2} \mathrm{O}$, and $\mathrm{P}_{2} \mathrm{O}_{5}$. However, because diverse analytical protocols, each with its own associated analytical precision and accuracy, were used to analyze samples, not all sources contain data for each of these constituents. Data in the "Fe2O3" and "FeO" columns are abundances of ferric and ferrous iron, respectively. Data in the "FeTO3" column represent total iron reported as ferric iron. To facilitate comparison of major oxide data for the Boulder batholith and its surrounding satellitic intrusions to those for other plutonic rocks, the compiled data are presented on several standard variation diagrams (figs. $3,4,5$ ).

\section{LOI, H2O+, H2O-, Tot_H2O, CO2, Cl, F, S, SO3, FeS2, and Tot_oth_sulf}

Data sources report volatile constituent concentrations for Boulder batholith samples in widely disparate ways. In order to capture important information concerning the volatile concentrations of these rocks, an array of data columns was designated to account for various analytical protocols and data reporting formats. Volatile constituents whose abundances were commonly determined include LOI (loss on ignition), $\mathrm{H}_{2} \mathrm{O}+$ (bound), $\mathrm{H}_{2} \mathrm{O}$ - (nonessential, moisture), and $\mathrm{CO}_{2}$. Several sources present data for total $\mathrm{H}_{2} \mathrm{O}$ without regard for species; these data are compiled in the "Tot_H2O" database column. Few sources contain $\mathrm{Cl}, \mathrm{F}, \mathrm{S}$, or $\mathrm{SO}_{3}$ abundance data. Several sources present iron and sulfur abundances for mineralized samples as $\mathrm{FeS}_{2}$. Finally, one source presents abundances of several sulfide species in moderately mineralized samples. These abundances were added and compiled in the "Tot_oth_sulf" column. All data are reported in weight percent.

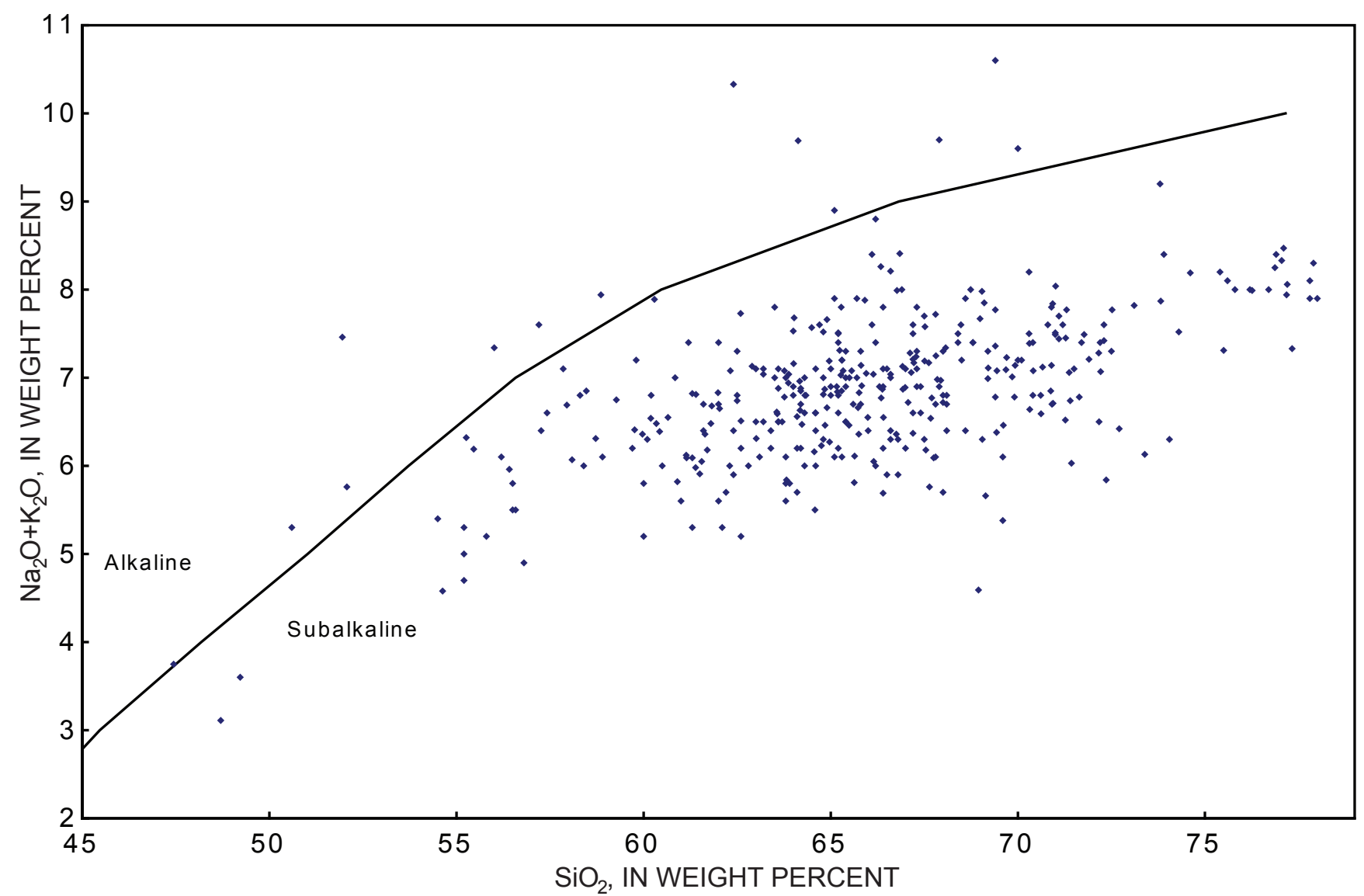

Figure 3. Total alkali-silica variation diagram showing compositions of the Boulder batholith and its satellitic plutons, southwest Montana. Alkaline and subalkaline fields defined by Irvine and Baragar (1971). 


\section{total}

One measure of major oxide analytical accuracy is how nearly the sum of the determined constituents approaches 100 percent. Consequently, the database includes a column that reports analytical totals (in weight percent) as reported by the source. Some sources do not include totals; totals for these samples were computed and added to the database. Initial analytical totals reported in the sources were spot checked for accuracy; discrepancies were noted and corrected in a number of cases.

\section{vol_sum}

The total volatile concentration of Boulder batholith samples provides some insight concerning whether abundances of other constituents accurately represent primary magmatic values. Samples with elevated volatile concentrations, for example greater than 3 weight percent, are likely to have experienced some fluid-mediated, post-magmatic chemical modification. Given the wide range of analytical protocols used in analysis of these samples, the best possible measure of sample volatile concentration is total volatile concentration. For the purposes of the compilation, if LOI data are the only information contained in source data compilations concerning volatile concentration, LOI values were designated as total volatile concentration. Alternatively, if the source includes data for any combination of $\mathrm{H}_{2} \mathrm{O}+, \mathrm{H}_{2} \mathrm{O}-$, Tot_ $\mathrm{H}_{2} \mathrm{O}, \mathrm{CO}_{2}, \mathrm{Cl}$, $\mathrm{F}, \mathrm{S}, \mathrm{SO}_{3}, \mathrm{FeS}_{2}$, or Tot_oth_sulf, these data were summed to yield total volatile concentration. All data are presented in weight percent.

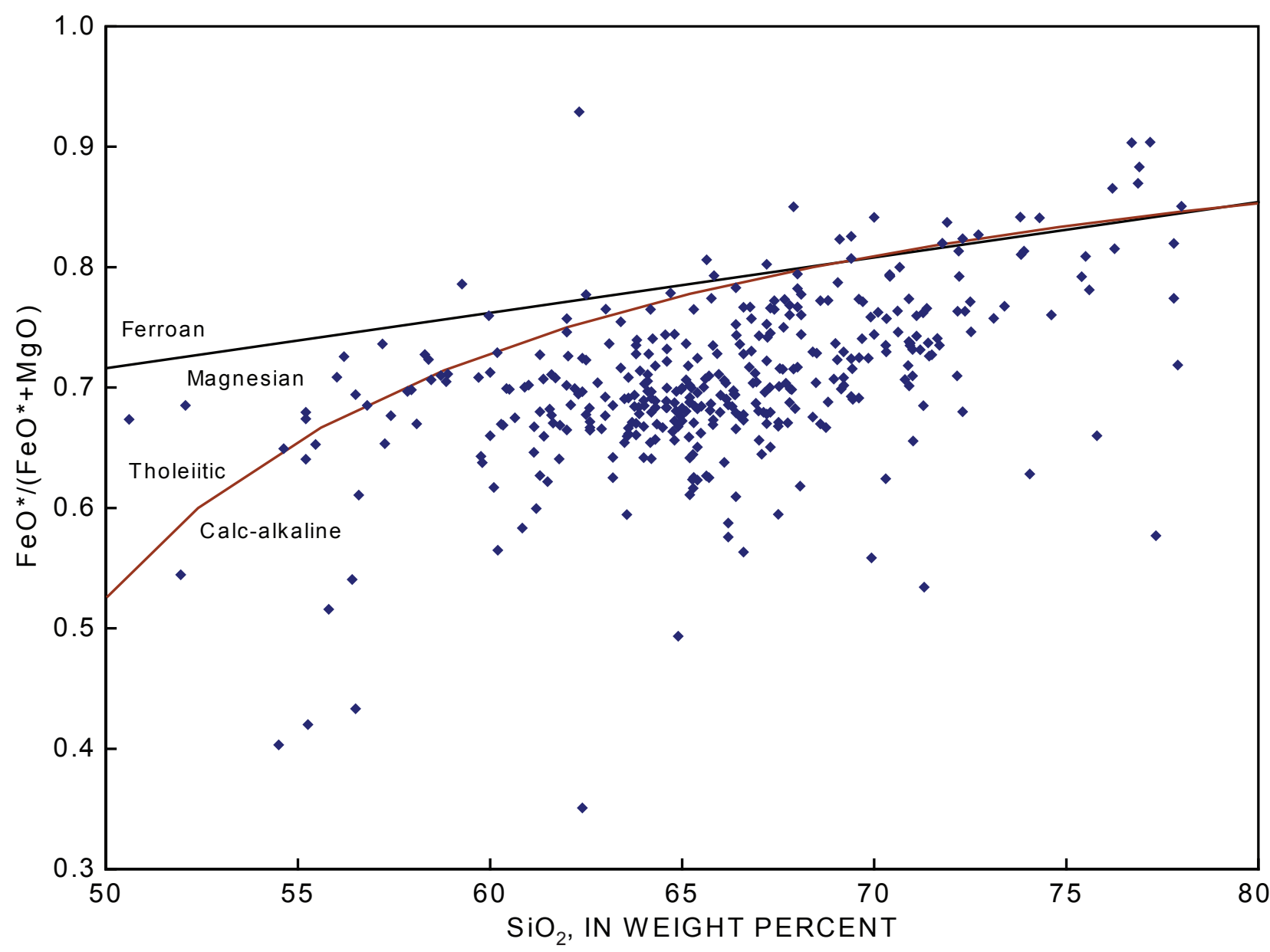

Figure 4. $\mathrm{Fe} 0^{*} /\left(\mathrm{FeO}{ }^{*}+\mathrm{MgO}\right)$ versus $\mathrm{SiO}_{2}$ variation diagram showing compositions of the Boulder batholith and its satellitic plutons, southwest Montana. $\mathrm{Fe}^{*}$, total iron expressed as ferrous iron. Ferroan versus magnesian boundary (black line) from Frost and others (2001); tholeiitic versus calc-alkaline boundary (red line) from Miyashiro (1974). 
$\mathrm{Ba}, \mathrm{Be}, \mathrm{Cs}, \mathrm{Rb}, \mathrm{Sr}, \mathrm{Y}, \mathrm{Zr}$, Hf, Nb, Th, U, Ga, La, Ce, $\mathrm{Pr}, \mathrm{Nd}, \mathrm{Sm}, \mathrm{Eu}, \mathrm{Gd}, \mathrm{Tb}, \mathrm{Dy}, \mathrm{Ho}, \mathrm{Er}, \mathrm{Tm}, \mathrm{Yb}, \mathrm{Lu}, \mathrm{Ag}$, $\mathrm{Au}, \mathrm{Co}, \mathrm{Cr}, \mathrm{Ni}, \mathrm{Sc}, \mathrm{V}, \mathrm{Cu}, \mathrm{Mo}, \mathrm{Pb}, \mathrm{Zn}, \mathrm{Sn}, \mathrm{W}$, Ta, As, Sb, and B

The sources present data for inconsistent sets of trace elements. Of these, data for $\mathrm{Ba}, \mathrm{Be}, \mathrm{Cs}, \mathrm{Rb}, \mathrm{Sr}, \mathrm{Y}, \mathrm{Zr}, \mathrm{Hf}, \mathrm{Nb}$, Th, U, Ga, La, Ce, Pr, Nd, Sm, Eu, Gd, Tb, Dy, Ho, Er, Tm, $\mathrm{Yb}, \mathrm{Lu}, \mathrm{Ag}, \mathrm{Au}, \mathrm{Co}, \mathrm{Cr}, \mathrm{Ni}, \mathrm{Sc}, \mathrm{V}, \mathrm{Cu}, \mathrm{Mo}, \mathrm{Pb}, \mathrm{Zn}, \mathrm{Sn}, \mathrm{W}, \mathrm{Ta}$, $\mathrm{As}, \mathrm{Sb}$, and $\mathrm{B}$ were compiled; all data are in parts per million. These constituents are among those for which sources most often contain data and also are considered sufficient to address many petrologic, tectonic, and metallogenic questions. To facilitate comparison of trace element data and their tectonic implications for the Boulder batholith and its surrounding satellitic intrusions to those for other magmatic arc rocks, the compiled data are plotted on a $\mathrm{Rb}$ versus $\mathrm{Y}+\mathrm{Nb}$ variation diagram (fig. 6).

\section{data_src}

Chemical, petrographic, and location data for each sample included in the database were compiled from primary data sources, in most cases a single source. For a few samples, data were culled from two or more sources; for example, major oxide data may have been compiled from one source and trace element data from another. Sources of geochemical information include publications of the USGS, unpublished USGS data, Master's and Doctoral theses, and published articles. Entries in the "data_src" column of the database are keyed numerically to sources identified in the following list:

1. Knopf (1957)

2. Ruppel (1963)

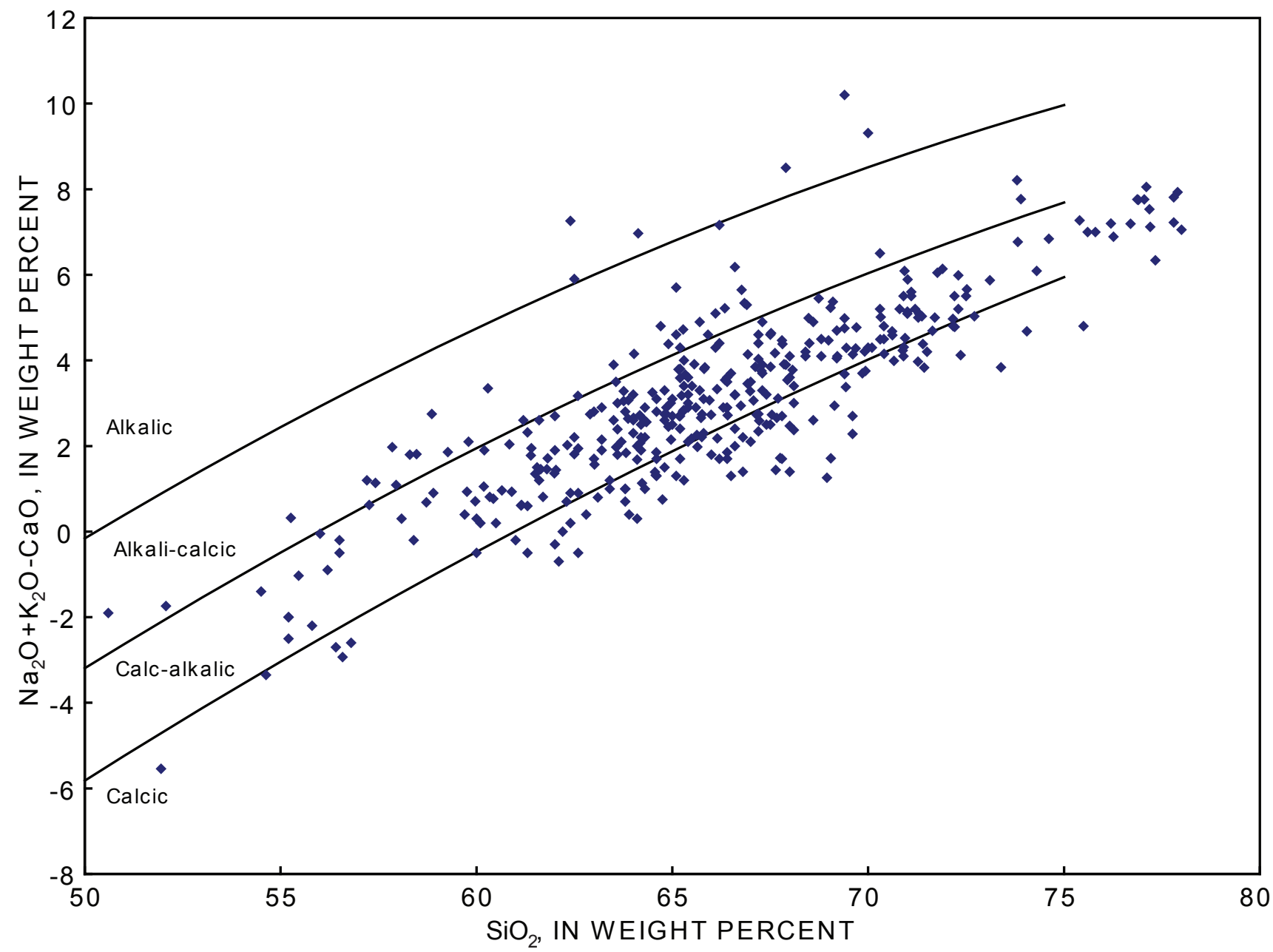

Figure 5. $\mathrm{Na}_{2} \mathrm{O}+\mathrm{K}_{2} \mathrm{O}-\mathrm{CaO}$ versus $\mathrm{SiO}_{2}$ variation diagram showing composition of the Boulder batholith and its satellitic plutons, southwest Montana. Boundaries between various rock series from Frost and others (2001). 
3. Tilling (1968)

4. Lambe (1981)

5. Weed (1912)

6. Weed (1901)

7. Becraft and others (1963)

8. Barrell (1907)

9. Klepper and others (1957)

10. Smedes (1966)

11. Shenon (1931)

12. Knopf (1913)

13. Tilling and Gottfried (1969)

14. Robinson and Barnett (1963)

15. Klepper and others (1971b)

16. U.S. Geological Survey, National Geochemical Database, 2008

17. Tilling, R.I., U.S. Geological Survey, unpub. data, 2008

18. Smedes and others (1973)

19. Lund, Karen, U.S. Geological Survey, unpub. data, 2008

20. Chapman, R.W., Trinity College, unpub. data, 1956
21. Castor and Robins (1978)

22. McClain, L.K., and Matthews, G.W., Bendix Corp., unpub. data, 1979

\section{rad_age}

The ages of several samples representative of Boulder batholith intrusions have been determined by U-Pb geochronology (Lund and others, 2002); these ages are compiled, in millions of years, in the database column titled "rad_age." Although numerous K-Ar age determinations of Boulder batholith samples have been made (McDowell, 1966; Tilling and others, 1968), these data were not included in the compilation because K-Ar geochronologic systems in the dated minerals (principally biotite and hornblende) were easily perturbed during the complex and protracted thermal history characteristic of an intrusion as large as the Boulder batholith.

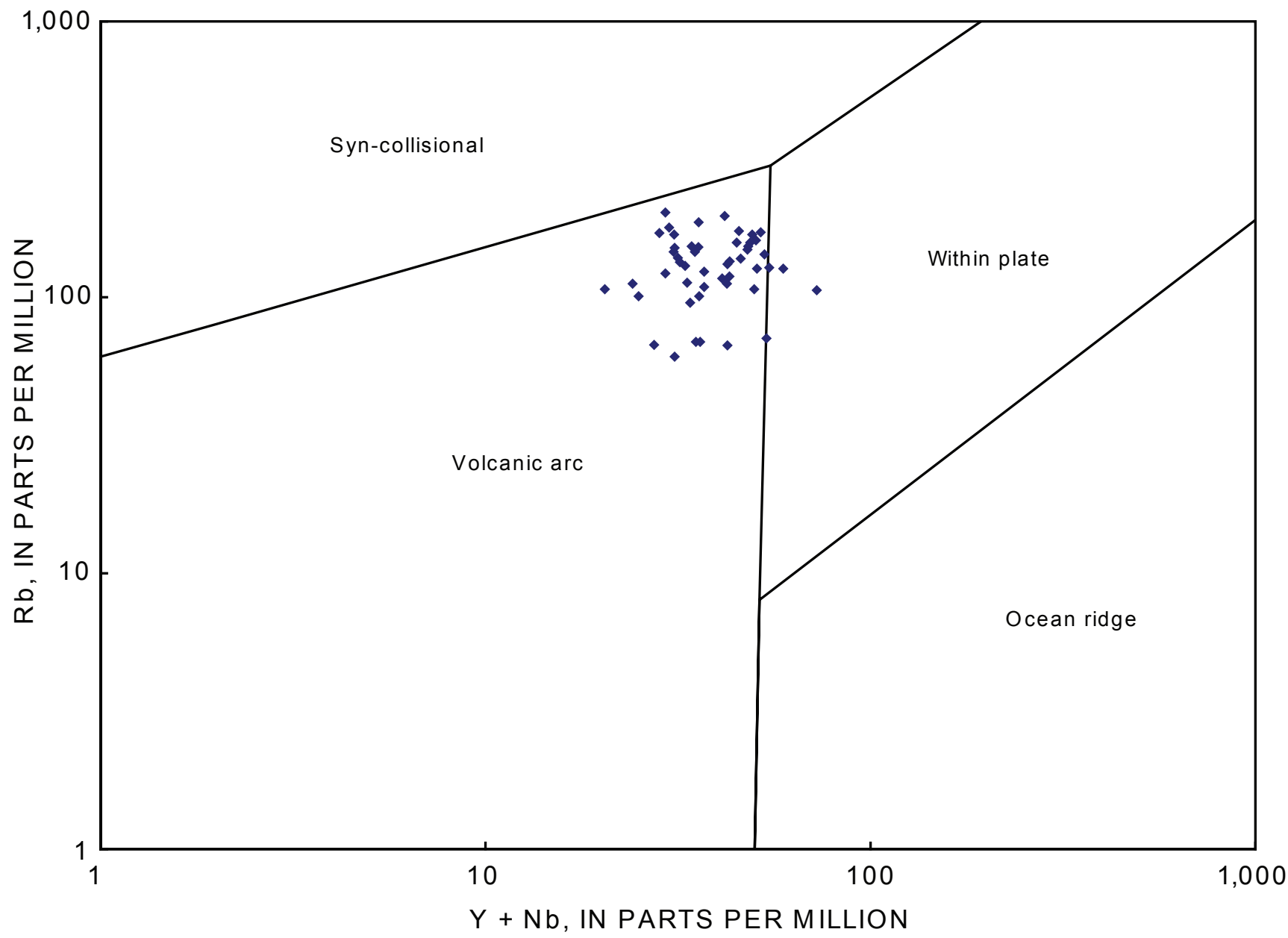

Figure 6. Trace-element, tectonic-setting-discrimination variation diagram showing composition of the Boulder batholith and its satellitic plutons, southwest Montana. Tectonic setting-composition boundaries from Pearce and others (1984). 


\section{uncert}

The database column titled "uncert" contains data, in millions of years, for the analytical uncertainties (as presented in the source) associated with each of the age determinations reported in the "rad_age" column.

\section{intrs name}

Most intrusions of the Boulder batholith, especially the largest, are named, either formally or informally; intrusion names are summarized by Smedes and others (1988). Many of the small satellitic plutons are named as well. Sources of names for these intrusions are summarized in the index to source data presented by Smedes and others (1988).

\section{Plag, Kspar, Otz, Hb, Pyx, Opx, Cpx, OI, Bi, Opq, Acc, Acces(incl opq), and Alt}

In addition to their geochemical characteristics, the composition of intrusive rocks can be quantified in terms of the relative abundances of the minerals they contain. This type of characterization, modal analysis, is accomplished by point counting either thin sections using a petrographic microscope or stained slabs using a low magnification binocular microscope. The effort involved in conducting these types of modal analyses is time consuming and difficult, with the consequence that this type of data is rarely collected. However, because modal data are precisely the type of information required to classify the composition of phaneritic intrusive rocks (Streckeisen, 1976), these data were compiled as well. This section of the database contains columns for the relative abundances (summing to about 100 percent) in volume percent of plagioclase (Plag), alkali-feldspar (Kspar), quartz (Qtz), hornblende $(\mathrm{Hb})$, pyroxene (Pyx), orthopyroxene (Opx), clinopyroxene (Cpx), olivine (Ol), biotite (Bi), opaque iron-titanium oxide minerals (Opq), accessory minerals, including zircon, titanite, apatite, allanite, and fluorite (Acc), accessory minerals plus opaque minerals (because some sources do not distinguish accessory from opaque minerals) (Acces(incl opq)), and alteration minerals, including epidote, sericite, carbonate minerals, chlorite, clay minerals, zeolite, and anhydrite (Alt). In some cases, sources do not separately quantify opaque mineral abundances; in these instances, opaque mineral abundances are presumed to be components of given accessory mineral abundances. An entry of "tr" in these columns signifies a trace amount, generally less than 0.1 percent, of the indicated constituent; and blank cells indicate that the constituent is not present.

\section{References Cited}

Barrell, Joseph, 1907, Geology of the Marysville mining district, Montana: U.S. Geological Survey Professional Paper 57, $178 \mathrm{p}$.

Becraft, G.E., Pinckney, D.M., and Rosenblum, Sam, 1963, Geology and mineral deposits of the Jefferson City quadrangle, Jefferson and Lewis and Clark Counties, Montana: U.S. Geological Survey Professional Paper 428, 101 p.

Brimhall, G.H., Jr., 1973, Mineralogy, texture, and chemistry of early wall rock alteration in the deep underground mines and Continental area, Butte district, Montana, in Miller, R.N., ed., Guidebook for the Butte field meeting of Society of Economic Geologists: Littleton, Colo., Society of Economic Geologists, p. H1-H5.

Brimhall, G.H., Jr., 1977, Early fracture-controlled disseminated mineralization at Butte, Montana: Economic Geology, v. 72, p. 37-59.

Brimhall, G.H., Jr., 1979, Lithologic determination of mass transfer mechanisms of multiple-stage porphyry copper mineralization at Butte, Montana-Vein formation by hypogene leaching and enrichment of potassium-silicate protore: Economic Geology, v. 74, p. 556-589.

Brimhall, G.H., Jr., 1980, Deep hypogene oxidation of porphyry copper potassium-silicate protore at Butte, Montana-A theoretical evaluation of the copper remobilization hypothesis: Economic Geology, v. 75, p. 384-409.

Brown, R.G., 1894, The ore deposits of Butte City: Transactions of the American Institute of Mining and Metallurgical Engineering, v. 24, p. 543-558.

Castor, S.B., and Robins, J.W., 1978, Preliminary study of uranium favorability of the Boulder Batholith, Montana: U.S. Department of Energy, Grand Junction Office, Colo., GJBX-5(78), 28 p.

Doe, B.R., and Tilling, R.I., 1967, The distribution of lead between coexisting K-feldspar and plagioclase: American Mineralogist, v. 52, p. 805-816.

Doe, B.R., Tilling, R.I., Hedge, C.E., and Klepper, M.R., 1968, Lead and strontium isotope studies of the Boulder batholith, southwestern Montana: Economic Geology, v. 63 , no. 8, p. 884-906.

Emmons, S.F., 1888, Notes on the geology of Butte, Montana: Transactions of the American Institute of Mining Engineers, v. 8, p. 49-63.

Emmons, S.F., and Tower, G.W., Jr., 1897, Economic geology of the Butte special district [Montana]: U.S. Geological Survey Atlas, Butte Folio No. 38, p. 3-8.

Frost, B.R., Barnes, C.G., Collins, W.J., Arculus, R.J., Ellis, D.J., and Frost, C.D., 2001, A geochemical classification for granitic rocks: Journal of Petrology, v. 42, p. 2033-2048. 
Gottfried, David, Rowe, J.J., and Tilling, R.I., 1972, Distribution of gold in igneous rocks: U.S. Geological Survey Professional Paper 727, 42 p.

Greenland, L.P., Gottfried, David, and Tilling, R.I., 1968, Distribution of manganese between coexisting biotite and hornblende in plutonic rocks: Geochimica et Cosmochimica Acta, v. 32, p. 1149-1163.

Greenland, L.P., Gottfried, David, and Tilling, R.I., 1974, Iridium in some calcic and calc-alkalic batholithic rocks of the western United States: Chemical Geology, v. 14, p. 117-122.

Greenland, L.P., Tilling, R.I., and Gottfried, David, 1971, Distribution of cobalt between coexisting biotite and hornblende in igneous rocks: Neues Jahrbuch für Mineralogie, Monatshefte, v. 1, p. 33-42.

Guilbert, J.M., and Park, C.F., Jr., 1986, The geology of ore deposits: New York, W.H. Freeman and Company, 985 p.

Hamilton, Warren, and Myers, W.B., 1967, The nature of batholiths: U.S. Geological Survey Professional Paper 554-C, $30 \mathrm{p}$.

Irvine, T.N., and Baragar, W.R.A., 1971, A guide to the chemical classification of the common volcanic rocks: Canadian Journal of Earth Sciences, v. 8, p. 523-548.

Johannsen, A., 1931, A descriptive petrography of the igneous rocks, Volume 1: Chicago, Ill., University of Chicago Press, 267 p.

Johnson, K.M., Doebrich, J.L., du Bray, E.A., and Foley, N., 2008, Mineral deposits research required for the next national mineral resource assessment-A collaborative opportunity: Geological Society of America Abstracts with Programs, v. 40, no. 1, p. 50.

Klepper, M.R., Robinson, G.D., and Smedes, H.W., 1971a, On the nature of the Boulder batholith of Montana: Geological Society of America Bulletin, v. 82, p. 1563-1580.

Klepper, M.R., Ruppel, E.T., Freeman, V.L., and Weeks, R.A., 1971b, Geology and mineral deposits, east flank of the Elkhorn Mountains, Broadwater County, Montana: U.S. Geological Survey Professional Paper 665, 66 p.

Klepper, M.R., Weeks, R.A., and Ruppel, E.T., 1957, Geology of the southern Elkhorn Mountains, Jefferson and Broadwater Counties, Montana: U.S. Geological Survey Professional Paper 292, 82 p.

Knopf, Adolph, 1913, Ore deposits of the Helena mining region, Montana: U.S. Geological Survey Bulletin 527, 143 p.

Knopf, Adolph, 1950, The Marysville Granodiorite stock, Montana: American Mineralogist, v. 35, p. 834-845.

Knopf, Adolph, 1957, The Boulder bathylith of Montana: American Journal of Science, v. 255, no. 2, p. 81-103.
Knopf, Adolph, 1963, Geology of the northern part of the Boulder bathylith and adjacent area, Montana: U.S. Geological Survey Miscellaneous Geologic Investigations Map I-381, scale 1:48,000.

Lambe, R.N., 1981, Crystallization and petrogenesis of the southern portion of the Boulder Batholith, Montana: Berkeley, Calif., University of California Ph. D. dissertation, 171 p.

Lange, I.M., and Cheney, E.S., 1971, Sulfur isotopic reconnaissance of Butte, Montana: Economic Geology, v. 66, p. 63-74.

Lund, Karen, 2007, Earth science studies in support of public policy development and land stewardship; Headwaters Province, Idaho and Montana: U.S. Geological Survey Circular $1305,92 \mathrm{p}$.

Lund, Karen, Aleinkoff, J.N., Kunk, M.J., Unruh, D.M., Zeihen, G.D., Hodges, W.C., du Bray, E.A., and O'Neill, J.M., 2002, Shrimp U-Pb and ${ }^{40} \mathrm{Ar} /{ }^{39} \mathrm{Ar}$ age constraints for relating plutonism and mineralization in the Boulder batholith region, Montana: Economic Geology, v. 97, p. 241-267.

McDowell, F.W., 1966, Potassium-argon dating of Cordilleran intrusives: New York, N.Y., Columbia University Ph. D. dissertation, $280 \mathrm{p}$.

Meyer, C., 1965, An early potassic type of wall-rock alteration at Butte, Montana: American Mineralogist, v. 50, p. 1717-1722.

Meyer, C., Shea, E.P., Goddard, C.C., Jr., Zeihen, L.G., Guilbert, J.M., Miller, R.N., McAleer, J.F., Brox, G.B., Ingersoll, R.G., Jr., Burns, G.J., and Wigal, T., 1968, Ore deposits at Butte, Montana, in Ridge, J.D., ed., Ore deposits of the United States, 1933-1967 (Graton-Sales Volume 2): New York, American Institute of Mining and Metallurgical Engineers, p. 1373-1416.

Miller, R.N., 1973, Production history of the Butte district and geological function, past and present, in Miller, R.N., ed., Guidebook for the Butte field meeting of Society of Economic Geologists: Littleton, Colo., Society of Economic Geologists, p. F1-F10.

Miyashiro, Akiho, 1974, Volcanic rock series in island arcs and active continental margins: American Journal of Science, v. 274, p. 321-355.

Pearce, J.A., Harris, N.B.W., and Tindle, A.G., 1984, Trace element discrimination diagrams for the tectonic interpretation of granitic rocks: Journal of Petrology, v. 25, p. 956-983.

Proffett, J.M., 1973, Structure of the Butte district, Montana, in Miller, R.N., ed., Guidebook for the Butte field meeting of Society of Economic Geologists: Littleton, Colo., Society of Economic Geologists, p. G1-G12.

Roberts, S.A., 1975, Early hydrothermal alteration and mineralization in the Butte district, Montana: Cambridge, Mass., Harvard University Ph. D. dissertation, 157 p. 
Robinson, G.D., and Barnett, H.F., 1963, Geology of the Three Forks quadrangle, Montana, with sections on Petrography of igneous rocks: U.S. Geological Survey Professional Paper $370,143 \mathrm{p}$.

Robinson, G.D., Klepper, M.R., and Obradovich, J.D., 1968, Overlapping plutonism, volcanism, and tectonism in the Boulder batholith region, western Montana: Geological Society of America Memoir 116, p. 557-576.

Ruppel, E.T., 1963, Geology of the Basin quadrangle, Jefferson, Lewis and Clark, and Powell Counties, Montana: U. S. Geological Survey Bulletin 1151, 121 p.

Rusk, B.G., Reed, M.H., and Dilles, J.H., 2008, Fluid inclusion evidence for magmatic-hydrothermal fluid evolution in the porphyry copper-molybdenum deposit at Butte, Montana: Economic Geology, v. 103, p. 307-334.

Rutland, C., Smedes, H.W., Tilling, R.I., and Greenwood, W.R., 1989, Volcanism and plutonism at shallow crustal levels-The Elkhorn Mountains Volcanics and the Boulder batholith, southwestern Montana: International Geological Congress, 28th, Washington, D.C., Field Trip Guidebook T337, p. 16-31.

Sales, R.H., 1913, Ore deposits at Butte, Montana: Transactions of the Society of American Institute of Mining, Metallurgical and Petroleum Engineers, p. 1523-1626.

Sales, R.H., and Meyer, C., 1948, Wall-rock alteration, Butte, Montana: Transactions of the American Institute of Mining, Metallurgical and Petroleum Engineers, v. 178, p. 9-33.

Sales, R.H., and Meyer, C., 1949, Results for preliminary studies of vein formation at Butte, Montana: Economic Geology, v. 44, p. 465-484.

Shenon, P.J., 1931, Geology and ore deposits of Bannack and Argenta, Montana: Montana Bureau of Mines and Geology Bulletin No. 6, 77 p.

Smedes, H.W., 1966, Geology and igneous petrology of the northern Elkhorn Mountains, Jefferson and Broadwater Counties, Montana: U.S. Geological Survey Professional Paper 510, $116 \mathrm{p}$.

Smedes, H.W., Klepper, M.R., and Tilling, R.I., 1973, The Boulder batholith, Montana, A summary, in Miller, R.N., ed., Guidebook for the Butte field meeting of Society of Economic Geologists: Littleton, Colo., Society of Economic Geologists, p. E1-E18.

Smedes, H.W., Klepper, M.R., and Tilling, R.I., 1988, Preliminary map of plutonic units of the Boulder batholith, southwestern Montana: U.S. Geological Survey Open-File Report 88-283, scale 1:200,000.

Streckeisen, Albert, 1976, To each plutonic rock its proper name: Earth-Science Reviews, v. 12, p. 1-33.

Tilling, R.I., 1964, Variation in modes and norms of an "Homogeneous" pluton of the Boulder batholith, Montana: U.S. Geological Survey Professional Paper 501-D, p. D8-D13.
Tilling, R.I., 1968, Zonal distribution of variations in structural state of alkali feldspars within the Rader Creek pluton, Boulder batholith, Montana: Journal of Petrology, v. 9, no. 3, p. 331-357.

Tilling, R.I., 1973, Boulder batholith, Montana-A product of two contemporaneous but chemically distinct magma series: Geological Society of America Bulletin, v. 84, p. 3879-3900.

Tilling, R.I., 1974, Composition and time relations of plutonic and associated volcanic rocks, Boulder batholith region, Montana: Geological Society of America Bulletin, v. 85, p. 1925-1930.

Tilling, R.I., 1977, Interaction of meteoric waters with magmas of the Boulder batholith, Montana: Economic Geology, v. 72 , no. 5 , p. $859-864$.

Tilling, R.I., and Gottfried, David, 1969, Distribution of thorium, uranium, and potassium in igneous rocks of the Boulder batholith region, Montana, and its bearing on radiogenic heat production and heat flow: U.S. Geological Survey Professional Paper 614-E, p. E1-E29.

Tilling, R.I., Klepper, M.R., and Obradovich, J.D., 1968, $\mathrm{K}$-Ar ages and time span of emplacement of the Boulder batholith, Montana: American Journal of Science, v. 266, p. 671-689.

Weed, W.H., 1901, Geology and ore deposits of the Elkhorn Mining district, Jefferson County Montana: U.S. Geological Survey Twenty Second Annual Report, part 2, p. 399-550.

Weed, W.H., 1912, Geology and ore depositions of the Butte district, Montana: U.S. Geological Survey Professional Paper 74, 262 p.

Manuscript approved for publication June 15, 2009

Publishing support provided by

Denver Publishing Service Center

For more information concerning this publication, contact

Science Center Chief Scientist, USGS Central Region Mineral Resources Box 25046, Mail Stop 973

Denver, CO 80225

(303) 236-1562

Or visit the Central Region Mineral Resources Science Center web site at http://minerals.cr.usgs.gov/ 